\title{
A Utilização da Arquitetura por Otávio Augusto NA Construȩão do Principado, de 31 A.C. À 27 A.C.
}

\author{
Macsuelber de Cássio Barros da Cunha ${ }^{1}$
}

RESUMO: No período que compreende o início do Principado, Roma foi palco de um extraordinário desenvolvimento e sofisticação no que concerne à arquitetura. Essa monumentalidade arquitetônica que se estabeleceu em Roma, teve em Otávio Augusto o seu maior idealizador, que se utilizou da arquitetura a fim de propagar uma imagem positiva de si e de seu governo. Tratamos neste trabalho sobre a forma como Augusto, entre os anos de 31 a.C. à 27 a.C., se utilizou da arquitetura, das construções e reconstruções de edifícios públicos para promover o engrandecimento da Vrbs e perpetuar seu nome e seus feitos na memória das futuras gerações. Dedicamos maior atenção ao ano de 29 a.C., quando Otávio Augusto regressou a Roma e após realizar seu triunfo consagrou alguns edifícios no Fórum Romano, promovendo uma verdadeira mudança topográfica neste espaço. Concentramos-nos também no ano de 28 a.C., quando Otávio empreende uma ampla restauração de mais de 80 templos, além de consagrar um novo templo dedicado a Apolo, no Palatino, demonstrando seu comprometimento com seus concidadãos e com os deuses, ressaltando ainda mais a pietas com que regia seus atos.

PALAVRAS-CHAVE: Otávio Augusto; Arquitetura; Principado; Propaganda.

ABSTRACT: In the period that includes the beginning of the Principate, Rome was the scene of an extraordinary development and sophistication with regard to architecture. This architectural monumentality that settled in Rome, had in Octavius Augustus its greater idealizer, so that this became a marked characteristic of its government. We deal in this work about the way in which Augustus, between the years $31 \mathrm{BC}$ and $27 \mathrm{BC}$, used architecture, constructions and reconstructions of public buildings to promote the aggrandizement of $\mathrm{Vrbs}$ and perpetuate his name and his achievements in the memory of future generations. We devoted more attention to the year $29 \mathrm{BC}$, when Octavius Augustus returned to Rome and after realizing his triumph he consecrated some buildings in the Roman Forum, promoting a real topographic change in this space. We also focus on the year $28 \mathrm{BC}$, when Octavius undertakes a vast restoration of more than 80 temples, as well as consecrating a new temple dedicated to Apollo in the Palatine, demonstrating his commitment to his fellow citizens and to the gods, emphasizing even more the pietas with which he governed his actions.

KEYWORDS: Octavian Augustus; Architecture; Principate; Propaganda.

\footnotetext{
${ }^{1}$ Doutorando em História pelo Programa de Pós-Graduação em História da Universidade Federal de Goiás, sob orientação da Profa. Dra. Ana Teresa Marques Gonçalves. Desenvolve pesquisa em História Antiga sobre a arquitetura e a escrita do De Architectura, de Vitrúvio, no período augustano. E-mail: macsuelber@hotmail.com.
} 
Introdução

No ano de 31 a.C. ocorreu uma batalha decisiva entre Roma e Egito, ou mais precisamente entre Otávio Augusto² e seu antigo companheiro de triunvirato, Marco Antônio. Na batalha naval de Ácio, se destacou a figura de Agripa ao lado de Otávio Augusto e, acompanhando Marco Antônio, estava Cleópatra. Após enfrentamentos estratégicos, Otávio e Agripa conseguiram vencer, sem conseguir, contudo, impedir a fuga de Marco Antônio e Cleópatra. No ano seguinte, Otávio Augusto invadiu o Egito. Em 1 de agosto deu-se o último confronto com Antônio, em Alexandria, onde, após a derrota, Marco Antônio se suicidou. Cleópatra foi capturada e iria figurar no cortejo triunfal de Otávio se não tivesse, como conta Plutarco (Antônio, LXXXVI), se deixado picar por uma áspide.

A vitória em Ácio pôs fim aos tempos turbulentos pelos quais Roma havia passado; tempo de fome, de insatisfação de parte da população, tempo de proscrições e perseguições políticas, de enfrentamentos entre grandes personalidades de Roma, fossem eles enfrentamentos políticos, propagandísticos, ideológicos ou militares; enfim, tempos de guerra civil e todas as mazelas que ela traz a um povo. A vitória sobre Marco Antônio foi um momento decisivo e de extrema importância para Otaviano, vitória esta que foi amplamente utilizada para a construção e consolidação de uma memória sobre o início do governo do futuro Augusto.

Apesar de ter sido o fim da guerra civil e, portanto, uma vitória sobre um romano, tal fato não transparece de modo claro na memória ${ }^{3}$ que foi perpetuada a partir de então, pois podemos ver uma preocupação por parte de Otaviano e seu grupo de apoio em mascarar este fato, alardeando que a vitória foi sobre o Egito e os perigos que Cleópatra representaria para Roma, pelo menos de acordo com

\footnotetext{
2 Convém ressaltarmos que, apesar de utilizarmos o nome Otávio Augusto no período tratado neste trabalho, o mesmo não era utilizado neste período, já que ele recebeu o título de Augusto apenas em 27 a.C. Do período que vai de 44 a.C. a 27 a.C. Otávio passou a adotar o mesmo nome de seu pai adotivo, de forma que alguns historiadores, para evitar confusões e com o propósito de diferenciação, optaram por chamá-lo nesse período como Otaviano, nomenclatura que também utilizamos ao longo do trabalho, embora o futuro Princeps nunca tenha usado esse nome para si.

3 Ao falar sobre a perpetuação de uma memória ou sobre a construção de uma memória, nos utilizamos neste trabalho, principalmente, daquilo que Joël Candau (2011, p. 23-24) chama de metamemória relacionada ao grupo. Para este autor, metamemória é a representação que cada indivíduo faz de sua própria memória, sendo, portanto, "uma memória reivindicada, ostensiva". Enquanto representação, a metamemória pode ser relacionada, em nível de sociedade, com a expressão memória coletiva, ou seja, "um enunciado que membros de um grupo vão produzir a respeito de uma memória supostamente comum a todos os membros desse grupo".
} 
o que foi propagado nos anos anteriores à vitória de Otaviano. Tal preocupação em ocultar o fato de Otaviano ter derrotado outros romanos pode ser percebida tanto na literatura do período, como também, e principalmente, nas Res Gestae escritas anos mais tarde, na qual Otaviano omite o nome dos rivais romanos por ele derrotados, como Sexto Pompeu e Marco Antônio. Tal fato é importante, pois demonstra a manipulação e seleção do que deveria ser inscrito na memória dos vindouros. A propaganda utilizada então pode ser definida como:

a construção e a difusão sistemática de mensagens, através de vários suportes disponíveis, destinadas a um público difuso [...], e visando criar uma imagem positiva de determinados fenômenos, articular uma imagem do governante e estimular determinados comportamentos ligados à adesão dos súditos a este governante (Gonçalves, 2013, p. 46).

Pensando nisso, temos como objetivo tratar da utilização da arquitetura por Otávio e seu grupo de apoio, após sua vitória em Ácio, como uma ferramenta de propaganda que visava criar uma imagem positiva do futuro Augusto e de seu governo; imagem na qual Otaviano figurava como aquele que havia restaurado a paz, após colocar fim às guerras civis. Para tratar acerca disso, damos maior atenção às atitudes de Otávio com relação à arquitetura, ao ano de 29 a.C., ano de seu regresso a Roma e ao ano de 28 a.C., quando ele teria reconstruído diversos templos em Roma.

\section{O Retorno do Triunfador em 29 a.C e as Construções no Fórum Romano}

A propagada e festejada vitória em Ácio e Alexandria rendeu ao general vitorioso diversas honrarias 4 concedidas pelo Senado.

As honras dadas a Otaviano após as vitórias sobre Antônio e Cleópatra em Ácio e Alexandria foram numerosas e acentuam tanto a grande importância de ambas as vitórias quanto de Otaviano, o provedor da vitória e da paz após a guerra civil e, esperançosa-

4 De acordo com Lange, “As honrarias eram uma parte importante do estado romano, e mais ainda durante o Triunvirato e o Principado. Elas eram usadas para negociações entre Princeps e seus sujeitos, mostrando lealdade, gratidão e apoio. O Princeps, por outro lado, teve que mostrar modéstia ao não aceitar todas, mas ao mesmo tempo sem ser ingrato" (Lange, 2009, p. 125). 
mente, provavelmente não apenas num nível ideológico e político, o portador da normalidade à Res Publica após uma turbulência. A ideologia deu aos romanos algo que eles queriam: paz - paz depois da guerra civil (Lange, 2009, p. 125).

Uma dessas honrarias conferidas pelo Senado, e que possuiu grande poder simbólico, foi o decreto para que as portas do Templo de Janus fossem fechadas. Este pequeno templo que se localizava no Fórum estava estritamente conectado com as noções de guerra e paz.

De acordo com Lawrence Richardson (1992, p. 207-208), a partir das fontes, sabe-se que o templo de Janus se localizava próximo ao ponto onde se iniciava o Argiletum5 no Fórum Romano. Existem várias versões sobre sua fundação; numa delas o templo teria sido construído por Rômulo e Titus Tatius em conjunto para mostrar a união das duas comunidades; no entanto, a versão mais difundida no período era a de que o templo havia sido fundado por Numa Pompilius. Sua estreita relação com guerra e paz se dava pelo fato de que, quando Roma estava em guerra, as portas do templo estavam abertas e quando Roma estava em paz, as portas do templo estavam fechadas. As portas do templo se mantiveram fechados ao longo do reinado de Numa; depois se fecharam novamente no período da Primeira Guerra Púnica; e pela terceira vez após a vitória de Otaviano.

Ainda segundo Richardson (1992, p. 207-208), a partir das moedas em que o templo foi retratado, ${ }^{6}$ podemos dizer que o mesmo parece ter tido uma pequena estrutura retangular de duas paredes longas de alvenaria sob uma ampla janela coberta por um conjunto de grades relativamente alto. Em uma extremidade são mostradas portas duplas emolduradas por colunas e uma estrutura arqueada. Presumivelmente, havia portas semelhantes na extremidade oposta. Não há indicações de um telhado, e presume-se que não havia nenhum. A antiga estátua de bronze do deus que acredita ter sido dedicada por Numa apresentava-se como um homem, mas com dois rostos idênticos voltados em direções opostas.

\footnotetext{
5 Argiletum era a principal via de acesso que conectava a praça central do Fórum e Suburra, passando entre a Cúria Julia e a Basílica Emília, antes da construção dos Fóruns Imperiais.

${ }^{6}$ Por exemplo, no sestércio cunhado em Roma em cerca de 66 d.C. (RIC I 326), no qual vê-se no anverso a efígie laureada de Nero com a inscrição IMP NERO CLAVD CAESAR AVG GER P M TR P P P; e no reverso o templo de Janus visto em perspectiva para a direita, com janela gradeada e guirlanda pendurada sobre as portas duplas fechadas, em torno do templo vemos a inscrição PACE P R TERRA MARIQ PARTA IANVM CLVSIT, S C.
} 
De acordo com Dion Cássio (História Romana, LI, 20), das diversas honrarias concedidas a Otaviano após suas vitórias, o fechamento das portas do templo de Janus seria a que mais o agradou. O próprio Otaviano fez questão de imortalizar este feito, demonstrando a importância que tal acontecimento teve em seu governo e a relevância do mesmo na memória que ele queria deixar registrada sobre si, de modo que registrou nas Res Gestae:

Era a vontade de nossos antepassados que as portas de Janus Quirinus fossem fechadas quando as vitórias garantissem a paz por terra e pelo mar em todo o Império do povo romano; desde a fundação da cidade até o meu nascimento, a tradição registra que foram fechadas apenas duas vezes, mas enquanto eu fui o Princeps, o Senado decretou que deveriam ser fechadas em três ocasiões (Res Gestae Diui Augusti, XIII).

Segundo Carsten H. Lange (2009, p. 144), uma possibilidade para a ausência de fechamentos de 235 a.C. a 29 a.C. pode sugerir que a ideologia do fechamento do templo não era geralmente reconhecida, outra é que o templo só se tornou um símbolo de paz com o futuro Augusto, embora algumas fontes destaquem a guerra mais do que a paz. Para este autor os três decretos para o fechamento das portas do templo no governo de Augusto, sugerem que, por trás do fechamento, não havia a ideia de uma paz duradoura; segundo ele, Varrão não menciona a palavra "paz", mas diz que as portas estavam sempre abertas, exceto quando não havia guerra em parte alguma. Lange conclui afirmando que o destaque dado para o lado pacífico do templo de Janus, a menção de paz e não guerra, parece uma invenção de Augusto.

Portanto, Otávio se utilizou desta honraria concedida pelo Senado para sublinhar sua imagem de restaurador da paz, ao derrotar os que, de acordo com seu discurso, ameaçavam Roma.

As portas fechadas do Templo de Janus simbolizam bem o papel de Otaviano. De todos os generais dos anos 40 e 30 a.C., ele sozinho conseguiu trazer a paz para a cidade no Tibre; ele sozinho tinha vingado César e lutado contra a ameaça do mal representada pelo Egito. Em 29 a.C., Otaviano ficou como o campeão da tradição romana e de Roma como sua personificação. Mesmo ocupado em batalhas a quilômetros de distância, ele explorou o patrocínio dos edifícios em Roma como um meio para legitimar sua herança política de Júlio César e estabelecer seu próprio valor como um triunfador individual e um campeão das tradições romanas (Favro, 2008, p. 102). 
Essa é, portanto, a autoimagem que Otaviano começou a moldar e propagar em seu governo. Não se sabe ao certo a data do fechamento das portas do templo de Janus. O mais provável é que tenha ocorrido antes da volta de Otaviano para Roma em 29 a.C., de forma que depois deste acontecimento memorável é que Otávio chegou a Roma e comemorou seu triplo triunfo7 com toda a pompa necessária para uma procissão tão especial e marcante na vida de um general e suas tropas. Seu triplo triunfo, sobre Ilíria, Alexandria e Ácio, foi um acontecimento magnífico, no qual a população pôde observar a grandeza de Otávio Augusto e a enorme riqueza que este trazia como butim de guerra. Pôde-se ver também uma representação (simulacrum) de Cleópatra, bem como seus filhos sobreviventes, Alexandre Hélio e Cleópatra Selene.

Atrás deles estava Otaviano, no carro tradicional puxado por quatro cavalos, e vestido com uma toga bordada com ouro e uma túnica com flores. Na cabeça levava uma coroa de louros, o símbolo da vitória. Normalmente, um general vitorioso seguia atrás dos detentores dos cargos do Estado e do Senado, porém, nesta ocasião, Otávio Augusto foi primeiro, em uma clara demonstração de seu predomínio político (Everitt, 2008, p. 243).

Desta forma, ao cruzar o Fórum Romano, as pessoas envolvidas na procissão puderam lançar o olhar ao pequeno templo de Janus e se lembrar do recente fechamento de suas portas associado ao fim das guerras e à paz trazida pela vitória de Otaviano.

Dias depois da realização da procissão triunfal, importantes edifícios localizados no Fórum Romano foram consagrados por Otávio Augusto. A consagração de tais edifícios foi um acontecimento de grande importância e relevância, marcando uma das primeiras medidas adotadas por Otaviano em 29 a.C. Tais medidas estavam intimamente relacionadas com a importância que a arquitetura desempenhou no governo de Otávio, servindo como estratégia política na criação e perpetuação de uma imagem positiva daquele que havia acabado com as guerras

\footnotetext{
7 Os triunfos eram cerimônias grandiosas, uma procissão ritual, em que o vitorioso líder desfilava através das ruas da cidade, à frente de suas tropas, apresentando seus espólios e seus prisioneiros para a população. Ele adentrava a cidade pelo portão triunfal, esplendidamente vestido e sobre uma quadriga (Beard et al, 1998, p. 44). Os triunfos se iniciavam no Campo de Marte, o deus da guerra, e além do comandante vitorioso e suas legiões, contava também com a presença de senadores, músicos e dos animais que seriam sacrificados no lugar de destino da procissão, o Capitólio (Everitt, 2008, p. 52-53).
} 
civis e com a ameaça oriental. A escolha do Fórum como o primeiro lugar a receber a atenção de Otaviano é expressiva, haja vista a importância simbólica, política e religiosa que o fórum desempenhou na Antiguidade.

O Fórum Romano era o coração de Roma, centro de poder onde se desenrolavam importantes atividades comerciais, políticas, religiosas, judiciais, de entretenimento, de sociabilidade, etc. Se constituía num amplo espaço aberto circundado por locais para comércio (tabernae), templos e outros edifícios públicos.

O Fórum foi estabelecido desde o início como o centro político e simbólico da cidade republicana, que passou a ser a capital da Itália no terceiro século a.C., dominando o mundo mediterrânico através da guerra e da conquista no próximo século. O Fórum foi um espaço público para uma variedade de atividades, incluindo reuniões políticas, distúrbios, combates de gladiadores e funerais (Watkin, 2009, p. 20).

Lewis Mumford (1998, p. 244) conta que, de acordo com a tradição, Roma era constituída pela união de várias tribos estrangeiras nas colinas próximas, lideradas pelos romanos situados no monte Palatino e que o símbolo desta união foi a fundação de um mercado comum a todos, o fórum, com um lugar de assembleia (comitium), que era também usado nos primeiros tempos para luta de gladiadores e disputas atléticas, sendo um templo, sem dúvidas, parte essencial e original do fórum.

Segundo Richardson (1992, p. 170-175), no início, o mercado provavelmente contava com simples bancas ao longo do que se tornou o Vicus Iugarius, onde os agricultores e pastores da cidade Palatina vendiam provisões; o local onde se desenvolveria o fórum possuía solo pantanoso, de modo que o real uso do vale parece ter começado com a canalização e o controle da Cloaca, e com o fórum seco e seguro, edifícios monumentais surgiram abaixo do Vicus Iugarius. Este mercado de Roma, com o tempo, evoluiu para o centro de negócios da cidade republicana. Os templos de Saturno e Castor foram dedicados nos primeiros anos da República. O Comitium, consagrado às assembleias públicas, eleições e legislação, ocupava a parte norte do Fórum, ligado à Cúria do lado norte. O Fórum também foi durante muito tempo o cenário de cerimônias e jogos. No século II a.C. foram construídas as Basílicas Pórcia, Fúlvia e Semprônia. A conversão do Fórum em um centro puramente cívico foi provavelmente não muito anterior ao 
tempo de Otaviano. No tempo de Sula foi construído o Tabularium no monte Capitolino, atrás do templo da Concórdia. A próxima grande obra no Fórum foi a de Júlio César em conexão com um esquema elaborado para reconstruir todo o complexo Comício/Cúria e as duas grandes basílicas.

De acordo com Diane Favro (1988, p. 17-19) em um breve artigo intitulado "The Roman Forum and Roman Memory", o Fórum Romano, como um ponto focal para energia comunal, não era apenas um espaço aberto em Roma. Ele era um receptáculo da consciência coletiva, de modo que durante a República cada vida romana girava em torno do Fórum; além disso, com todos seus monumentos e edifícios, o Fórum Romano poderia fornecer uma verdadeira aula sobre a história republicana, já que "cada construção, cada espaço, cada pedra tinha uma história e uma moral, cada indivíduo nomeado ou retratado levantava-se como exemplar".

Pierre Gros (2002, p. 207) também trata sobre a importância que a memória desempenhava nos fóruns antigos ao dizer que a concentração de edifícios religiosos e administrativos, tanto quanto de monumentos comemorativos e inscrições honoríficas, fez do fórum um verdadeiro monumentum, um "lugar de memória”, mas de uma memória que é a condição mesma do funcionamento das instituições da vida da comunidade.

David Watkin (2009, p. 16) nos esclarece que ao longo da história romana, o vínculo entre religião e poder foi demonstrado pelos líderes políticos que fundaram templos para enfatizar sua autoridade; o Fórum Romano foi o lugarchave desta exibição simbólica. Tais edifícios podem ser financiados pelos frutos das campanhas militares e ser ofertas de agradecimento aos deuses, bem como fixar na memória a história romana e aumentar o prestígio de Roma.

Não é de se admirar, portanto, que o Fórum Romano tenha sido passagem obrigatória para as procissões triunfais, ou que Otaviano tenha dedicado tanta atenção a este centro simbólico da cidade, que dentre os principais edifícios, 
podemos citar: o templo de Saturno, ${ }^{8}$ o erário da cidade; o templo de Vesta, 9 templo circular onde era mantido o fogo sagrado da cidade; os templos da Concórdia e de Castor e Pólux; a Cúria;10 a Régia; ${ }^{11}$ as basílicas ${ }^{12}$ Emília e Júlia; e o cárcere. ${ }^{13}$

Este complexo também reflete a ideologia que seria desenvolvida por Otaviano, que se baseou na manutenção de um delicado equilíbrio entre continuidade e inovação - uma conexão com o passado republicano e reconhecimento de um grande futuro imperial (Sumi, 2011, p. 205).

Sendo assim, o Fórum Romano, ou Fórum Magno, após ter sido palco da cerimônia de fechamento das portas do templo de Janus, simbolizando o fim das guerras; e após ter recebido a procissão do triplo triunfo de Otaviano, entre os dias 13 e 15 de agosto de 29 a.C., deu lugar a mais cerimônias e festejos, nas quais Otávio Augusto teve papel de destaque, e tudo isso apenas 3 dias após seu triplo triunfo, mostrando com isso a importância que tais atos desempenharam para a figura pública de Otaviano, já que foram as primeiras coisas a serem feitas após a sua chegada a Roma. Passamos agora a tratar sobre os edifícios inaugurados por Otaviano no Fórum Romano, começando pelo templo dedicado ao seu pai adotivo.

O templo do Diuus Iulius foi prometido e iniciado ainda no tempo do triunvirato e, portanto, de responsabilidade não só de Otaviano, como também de Antônio e Lépido. No entanto, Otaviano em suas Res Gestae escreve que tal templo é uma construção sua, sem mencionar o nome dos outros dois, de modo a passar para a posteridade que tal obra era um feito unicamente seu (Res Gestae Diui Augusti, XIX).

\footnotetext{
${ }^{8}$ É provável que tenha sido construído no começo da República. O templo continha o tesouro do estado, o Aerarium Populi Romani ou Aerarium Saturni.

9 De acordo com a tradição, o templo de Vesta foi construído pela primeira vez por Numa Pompílio, fundador da ordem das Vestais.

${ }^{10}$ Edifício no qual se reuniam os Senadores.

${ }^{11}$ Pequeno edifício que ficava do lado leste do Fórum Romanum entre a Via Sacra e o Templo de Vesta. Teria sido construído por Numa, que vivia nela ou a usava como sede. Também se diz que foi a casa do Pontifex Maximus, embora no período histórico ninguém pudesse ter vivido na Régia, pois era um templum consagrado contendo sacraria. A casa real do Pontifex Maximus era provavelmente a Domus Publica, ligada ao Atrium Vestae (Richardson, 1992, p. 328).

${ }^{12}$ As basílicas serviam especialmente como salas de negócios, os lugares onde os banqueiros montaram suas mesas e coisas do gênero. Local privilegiado para a realização de tribunais. O espaço livre fornecido pelas basílicas estimulou a expansão de seu uso (Richardson, 1992, p. 50).

${ }^{13}$ A única prisão pública de Roma. Não era um lugar de longa prisão, simplesmente um lugar de detenção, e especialmente o lugar onde os condenados de crimes capitais eram executados.
} 
O templo de César, construído no local de sua cremação, se localizava no lado leste do Fórum Romano (Figura 01), em estreita ligação com a Régia, e ligou o novo deus com os reis antigos e com as formas oficiais da atual religião do estado, devido à importância da Régia neste aspecto. Os despojos da conquista do Egito foram usados como rica decoração interior, que incluiu a famosa pintura de Vênus Anadyomene, do mestre grego Apelles. A importante localização do templo e o alto pódio exibiram proeminentemente uma colunata coríntia para o público romano, e este exemplo inicial de estilo imperial, escondendo as paredes antigas e irregulares da Régia, deu ao Fórum um elegante novo término a leste. $\mathrm{O}$ Templo de César e a Régia tornaram-se parte do mesmo complexo, dando conceitualmente a César uma posição proeminente tanto no panteão romano como no governo imperial sob sua proteção (Gorski e Packer, 2015, p. 85).

Apesar de aparecer nas moedas ${ }^{14}$ como um templo tetrástilo, a partir das descobertas arqueológicas sabe-se que o templo era hexástilo. ${ }^{15}$ De acordo com Vitrúvio (De Architectura, III, 3, 2) o templo era picnostilo. ${ }^{16}$ Tanto o pronaos ${ }^{17}$ quanto a cela ${ }^{18}$ eram retângulos largos de igual profundidade. A partir de fragmentos que nos chegaram, se deduz que a ordem era Coríntia. A estátua de culto representava César com uma estrela (o Sidus Iulium) acima de sua cabeça. "Além disso, a cela do templo, com suas portas mais largas e a frente mais aberta, foi projetada menos como um santuário e mais como um espaço de exibição para a estátua de culto" (Sumi, 2011, p. 221).

\footnotetext{
${ }^{14}$ Em moedas de ouro (RRC 540/1) cunhadas por Otaviano, nas quais em seu anverso podemos ver a sua efígie, em torno da qual se encontra a inscrição IMP. CAESAR· DIVI· F. III. VIR· ITER . R. P. C, Imperator César, filho de um Divus, Triúviro pela segunda vez para a manutenção da República. No reverso vemos a imagem de um templo tetrástilo sobre um pódio; no interior do templo pode-se ver uma figura velada, que deve ser a representação da estátua cultual, segurando um lituus na mão direita; no tímpano do templo vemos a representação do cometa (Sidus Iulium) e na arquitrave a inscrição DIVO-IVL, Divino Júlio; ao lado esquerdo do templo vemos um altar; em torno do qual encontra-se a inscrição COS·ITER·ET.TER·DESIG, Cônsul pela segunda vez e designado para um terceiro consulado.

${ }_{15}$ Com seis colunas frontais.

16 "Picnóstilo é o templo onde se pode preencher o intercolúnio com um diâmetro e meio de coluna, como acontece no templo do Diuus Iulius, no templo de Vênus no Fórum de César e em outros que dessa feição se encontram planeados" (Vitrúvio. De Architectura, III, 3, 2).

${ }^{17}$ Era a antecâmara do templo que antecedia a cela.

${ }^{18}$ Era a estrutura central do templo, na qual ficava a estátua da divindade.
} 


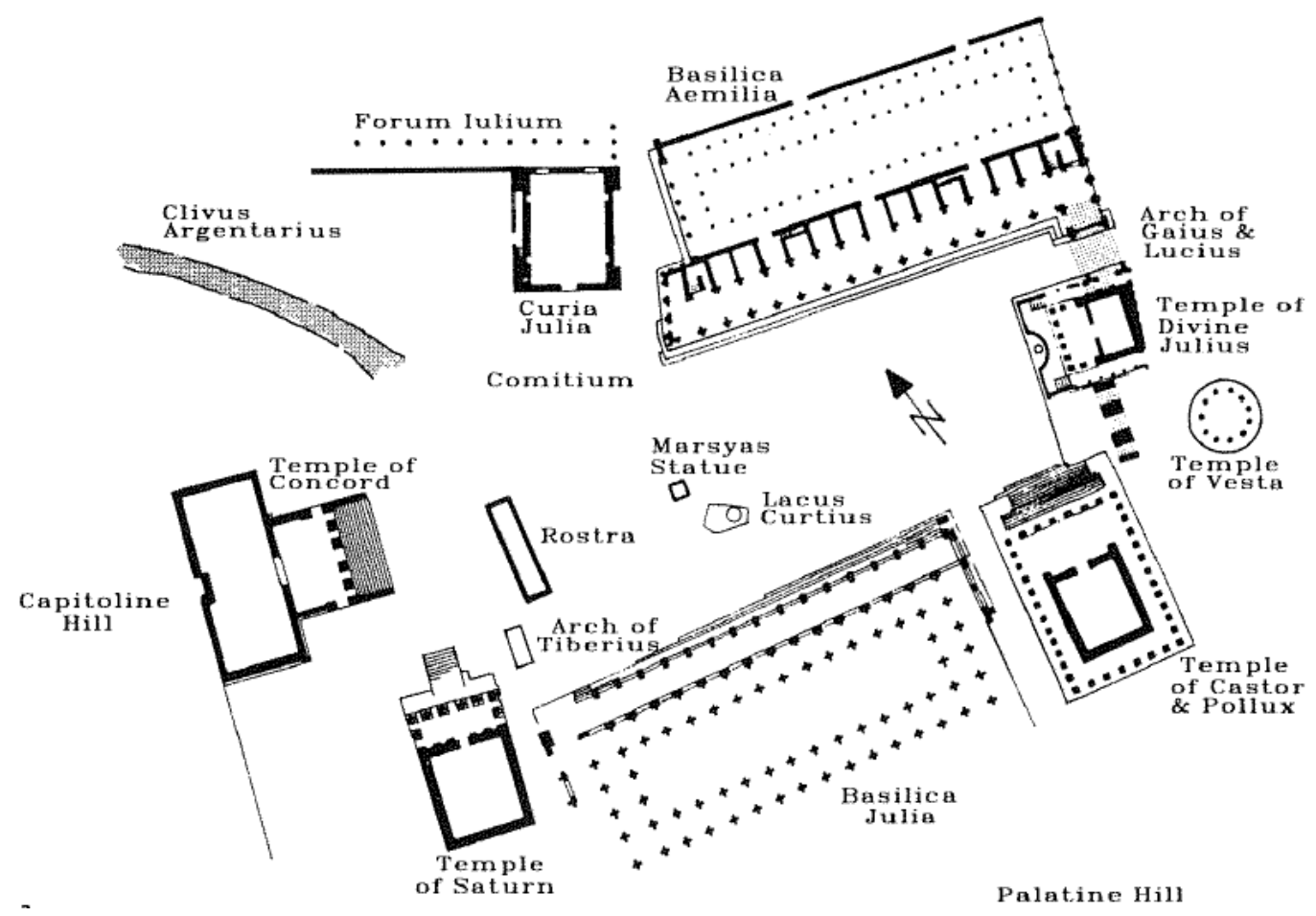

Fig. 1: Fórum Romano, por volta de 20 d.C. (Favro, 1988, p. 19)

A configuração do templo é bastante interessante, pois, como era costume na construção de templos em Roma, o templo de César ficava no alto de um pódio, mas sua escadaria de acesso não ficava em frente ao pódio e sim nas laterais. ${ }^{19}$ Com isso, a parte frontal do pódio ficou livre para que Otávio orgulhosamente dispusesse os rostra dos navios da batalha em Ácio. Com isso, o templo prestava as devidas honras ao nome de Júlio César, que tinha ascendido à categoria de Diuus, junto a isso o templo exaltava o nome e a pietas de Otaviano, o diui filius; mas o templo também serviu como um monumentum à vitória em Ácio, comemorando o fim das guerras civis e o estabelecimento da paz, exaltando a imagem do mais recente triunfador.

Além disso, como lembra Sumi (2011, p. 222), o templo do Diuus Iulius estava diretamente em frente à principal plataforma de oradores do Fórum, a Rostra Augusti, e a decoração da parte frontal do pódio do templo com os rostra de navios capturados em Ácio respondia tematicamente aos rostra dispostos na

\footnotetext{
19 De acordo com Gilbert Gorski e James Packer (2015, p. 86), durante o governo de Otaviano, o templo passou por três estágios. No primeiro, uma escada paralela a cada lado do pódio levava à plataforma do orador. O nicho semicircular no centro do pódio emoldurou um altar, e uma escada central levou desde o pódio ao pórtico e à cela. No segundo período, Otaviano ampliou o pódio, moveu as escadas do pódio para as extremidades da fachada da Rostra, fechou o nicho do altar e instalou os esporões dos navios da batalha em Ácio. Na terceira fase, uma arcada de um andar emoldurou os lados e a parte de trás do templo.
} 
Rostra Augusti, forjando, assim, não apenas uma ligação visual entre a nova Rostra e a antiga, mas também uma conexão ideológica: ambas as plataformas preservavam os despojos das vitórias navais que salvaram a República, e assim equipararam as conquistas do novo regime com as da antiga República.

A Rostra Augusti localizada no lado oeste do fórum teria sido iniciada por Júlio César, em substituição à Rostra que ficava junto ao Comitium, em frente à Cúria Hostília. ${ }^{20}$ Otaviano foi o responsável por terminar a Rostra e decorá-la com os rostra dos barcos de Ácio.

A outra construção no Fórum Romano iniciada por César e concluída por Otaviano, e que também foi inaugurada neste ano de 29 a.C., foi a Cúria Júlia. Tal edifício foi iniciado por César no início de 44 a.C., em substituição à Cúria Hostília que havia sido demolida. Otaviano igualmente dedicou um altar e uma estátua à deusa Vitória. Junto à Cúria que Otaviano concluiu, estava também o Chalcidicum, um pórtico ligado à frente da Cúria, que ficava voltada para o Fórum Romano. A parte traseira da Cúria se ligava aos pórticos que cercavam o Fórum de César.

Outro importante edifício do Fórum Romano, que também foi iniciado por César e concluído por Otávio, embora não tenha sido dedicado em 29 a.C., é a Basílica Júlia. O grandioso edifício foi iniciado por Júlio César para substituir a Basílica Semprônia de 170 a.C., provavelmente por volta de 54 a.C., com os despojos das guerras Gálicas, e dedicado inacabado em 46 a.C., de modo que após a morte de César, Otaviano termina a construção.

Percebe-se, assim, que neste período de transição entre a República e o Principado, ocorreu uma verdadeira mudança topográfica do Fórum Romano, coração da cidade e essencialmente um lugar de memória. Tal mudança, iniciada por César e concluída por Otaviano, colocava este último em lugar de destaque, exaltando a figura do general vitorioso que pôs fim às guerras civis, sendo perpe-

${ }^{20}$ A Cúria Hostília teria sido construída por Túlio Hostílio, juntamente com a área de votação (Comitium) para a primeira assembleia popular de Roma. Em 81 a.C. foi reconstruída por Sula. Em 52 a.C., Fausto Sula restaurou a Cúria. Alguns anos mais tarde foi novamente demolida e no início de 44 a.C. o Senado atribuiu sua reconstrução a César, que deu início à construção da nova Cúria alinhada com a colunata do seu novo Fórum, do qual falamos mais à frente (Gorski e Packer, 2015, p. 117-119). 
tuado na memória como o restaurador da paz. Sua imagem se ligava à nova divindade do panteão romano, ao diuus Iulius, seu pai adotivo e iniciador de tais reformas arquitetônicas.

Para Zanker (2005, p. 103-106), a reestruturação do Fórum Romano ofereceu um exemplo demonstrativo de como Otaviano ocupou a cidade com seus edifícios e os signos de sua vitória, visto que os novos edifícios inaugurados eram ricamente decorados com motivos que se ligavam à vitória de Ácio. De acordo com Sumi:

Uma das primeiras tarefas de Otaviano após Ácio era completar a nova topografia do Forum Romanum que César tinha iniciado. A consagração da Cúria Júlia topograficamente marcou o fim de uma era ao completar a nova orientação do Fórum, com a Cúria, um símbolo do poder e prerrogativa senatorial - na verdade, um símbolo da própria República - que virou-se para a nova Rostra Augusti. [...] A remoção da Rostra para longe da Cúria separou o orador topograficamente e simbolicamente da influência do Senado. [...] A nova topografia do Fórum insinua uma redefinida distribuição de poder político sob o Principado (Sumi, 2008, p. 223).

A nova configuração do Fórum Romano enaltecia César e Otaviano, tornando suas imagens ostensivamente presentes em diversos pontos do fórum por meio das histórias às quais cada edifício se ligava, tornando memoráveis o nome e os feitos de seus idealizadores, de tal forma que uma pessoa que se posicionasse no centro do amplo espaço aberto do Fórum Romano podia ver obras relacionadas a César/Otaviano nos quatro lados que cercavam este espaço retangular. Em um dos lados, erguia-se a magnífica e grandiosa Basílica Júlia, uma das maiores construções do fórum; no lado oposto, ao lado da belíssima Basílica Emília, se encontrava a Cúria Júlia; no outro lado, no extremo oeste do Fórum, achava-se a importante Rostra Augusti, decorada com os rostra dos barcos de Ácio; e do lado oposto, no extremo leste, erguia-se o mais novo templo do Fórum, dedicado à mais nova divindade cultuada em Roma, o divino Júlio César, pai de Otávio, templo este que também lembrava a batalha em Ácio. Deste modo, associações com Otaviano poderiam ser vistas dos quatro lados do fórum, por meio de importantes construções (fig. 1).

Como podemos ver, Otaviano se utilizou da arquitetura, das construções e reconstruções de edifícios públicos e da mudança na topografia do Fórum para assegurar que uma imagem positiva de si fosse transmitida à população. 


\section{A Utilização da Arquitetura para o Engrandecimento da Urbs}

Otávio Augusto, portanto, se utilizou da arquitetura nos anos posteriores à sua vitória naval de modo a promover o engrandecimento da Vrbs e conferir a ela importantes edifícios públicos que serviam para propagar o seu nome e seus feitos. Evidentemente não podemos deixar de dizer que a utilização da arquitetura para o enaltecimento de Roma já era uma prática comum antes de Otávio Augusto, em virtude de que tais empreendimentos elevavam o prestígio daqueles que propiciavam tais obras para a cidade. Este aspecto pode ser visto, por exemplo, no que concerne à construção de templos, pois, de acordo com Eric Orlin (2002, p. 67), na obra intitulada Temples, Religion, and Politics in the Roman Republic, os generais, ao prometerem e construírem templos durante a República, poderiam criar a imagem de um indivíduo que colocava os interesses do Estado acima dos interesses próprios, visto que a construção de um templo servia aos "melhores interesses do Estado". Ainda com relação à construção de templos, podemos citar Adam Ziolkowski (1992, p. 307) que, ao longo de sua obra, demonstra como a construção de templos foi amplamente utilizada durante a República, em especial a partir do quarto século a.C., pois, segundo este autor, mais de 50 templos foram construídos entre 396 e 219 a.C. e cerca de 35 foram construídos entre 218 e 50 a.C.

Apesar deste grande número de construções durante a República, alguns autores defendem que tais empreendimentos não se comparam com os feitos de Otávio Augusto durante seu governo. Diane Favro (2007, p. 235), por exemplo, defende que antes do fim do primeiro século a.C., esforços para o engrandecimento de Roma foram episódicos e que mesmo as magníficas obras arquitetônicas erguidas por generais durante o segundo e primeiro séculos a.C. tiveram um impacto coletivo limitado, não conseguindo transformar Roma. "Apenas quando o poder se concentrou sob um homem que a preocupação com a imagem urbana de Roma como um todo começa a ser abordada. Júlio César foi um dos primeiros a pensar globalmente sobre Roma" (Favro, 2007, p. 235). Numa perspectiva semelhante trabalha Valerie Hope, ao afirmar que:

Foi durante o primeiro século antes de Cristo, contudo, e nas mãos de proeminentes homens como Sula, Pompeu e Júlio César, que a cidade cada vez mais ganhou os símbolos 
físicos de poder. Competição aristocrática encorajou tais homens a embelezar Roma como um meio de aumentar seu próprio prestígio (Hope, 2005, p. 65).

Sob este mesmo prisma está o trabalho de Claudia Beltrão (2006, p. 144), ao afirmar que o interesse pelas construções e inovações do espaço público religioso - e que demonstrava o quanto os romanos eram cuidadosos e preocupados com a sua vida religiosa, era algo que já estava presente nas gerações anteriores, porém se desenvolvendo agora em uma escala espetacular:

Nesta expansão e reconstrução de Roma, templos e monumentos religiosos tiveram um papel predominante. Em termos gerais, um magnífico dispêndio de tempo, dinheiro e esforço foi posto em monumentos religiosos tanto antes como depois da "queda da República” e do estabelecimento do novo regime. Não é exagero dizer que a competição entre os líderes políticos da República tardia travou-se, em grande medida, em termos da linguagem religiosa (Beltrão, 2006, p. 144).

Deste modo, Otávio Augusto deu continuidade a uma tradição que César, entre outros, já havia utilizado em grande medida. Porém, na época em que César empreendeu o melhoramento de Roma através da arquitetura, criou-se o rumor de que ele, assim o fazendo, demonstrava que a cidade não era boa o suficiente para ele, e seu relacionamento com Cleópatra agravou ainda mais tais rumores. Pairava no ar o receio de que o centro do poder deixasse Roma em direção de Alexandria. Desta forma, quando ele foi assassinado em 44 a.C., muitas de suas obras ainda não haviam sido concluídas.

Rumores semelhantes giraram em torno de Marco Antônio e seu relacionamento com Cleópatra, muitos dos quais eram propagados pelo próprio Otávio Augusto de modo a difamar seu oponente. Um dos fatos que foi utilizado por Augusto como uma propaganda negativa contra Marco Antônio foi o testamento deixado por este com as Vestais e que expressava seu desejo de ser enterrado junto a Cleópatra. Esta informação foi propagada por Otávio Augusto de modo a criar uma imagem positiva de si próprio, na medida em que atacava a imagem do outro e que passava uma imagem do outro enquanto traidor dos costumes próprios de Roma.

A preservação da centralidade de Roma e a garantia do elusivo fenômeno da identidade Romana continuaram a ser o ponto de manipulação nos anos finais da República. Otaviano, o jovem herdeiro de Júlio César que foi mais tarde nomeado Augusto, alinhou-se 
com a cidade e todas suas tradições. A propaganda de Otaviano contrapôs isso com a deslealdade de seu oponente Antônio que caiu sob a influência oriental de Cleópatra e da realeza (Hope, 2005, p. 72).

Em razão disso outra medida que Otaviano tomou em 29 a.C., foi iniciar a construção de seu mausoléu, como forma de deixar claro sua intenção de ser enterrado em Roma, afastando assim qualquer possibilidade de que acontecesse com ele o mesmo que aconteceu com César e com Antônio. Seu mausoléu era "um contraste agudo ao desejo de Antônio, uma afirmação arquitetural que garantia a presença contínua de Otávio Augusto em Roma, após sua morte, e declarava que a capital não poderia ser movida” (Haselberger, 2007, p. 50). O mausoléu de Otávio Augusto teria na época 87 metros de largura e quase 40 de altura. Era uma gigantesca obra arquitetônica localizada no Campo de Marte, demonstrando a riqueza, a grandeza e o poder do seu patrono.

Desta forma, Otaviano dava continuidade, nestes primeiros anos sem Antônio, à incrível empreitada cujo resultado seria transformar Roma em uma cidade digna de ser a capital de um vasto império territorial. Ele "converteu Roma em um lugar digno tanto do Imperador quanto do Império, embelezando e melhorando a cidade” (Hope, 2005, p. 75). Por meio da arquitetura, Otaviano promoveu o engrandecimento de Roma e a propagação de uma imagem positiva de si e de seu governo.

\section{A Importância da Arquitetura Religiosa}

Em 28 a.C., Otávio Augusto recebeu o título de Princeps, título este que deu origem ao termo "Principado" que passou a nomear a forma de governo que se iniciou com ele, mas, apesar de usarmos este termo, Erich Gruen (2007, p. 3334) esclarece que este conceito, em referência à forma de governo, só se tornou de uso comum após Augusto, de tal modo que em seu tempo o termo não era utilizado do mesmo modo que, por exemplo, na época de Tácito. Otaviano, quando se refere a si como Princeps, se utiliza do vocábulo que já era usado na República e que era "uma designação de figura influente, um sinal de estima e autoridade".

Neste mesmo ano, ele buscou demonstrar ainda mais fortemente sua pietas e seu compromisso com a religião e com o mos maiorum, ao empreender um 
grande esforço de restauração religiosa, no qual dentre as tarefas realizadas estava a de restaurar os antigos templos localizados na Urbs, que haviam ficado relativamente abandonados por aqueles que deveriam cuidar de tais obras, devido principalmente aos problemas advindos das guerras civis. Posteriormente, Horácio escreveu no terceiro livro das Odes que os romanos pagariam pelos erros de seus ancestrais até que cada templo em ruínas fosse restaurado (Horácio Carminum, III, 6). Tito Lívio, outro contemporâneo de Augusto, deixa entrever no livro quarto de sua obra este importante papel de Otávio Augusto enquanto restaurador dos antigos templos, tratando-o como "fundador ou restaurador de todos os santuários" (Tito Lívio. Ab Urbe Condita, IV, 20, 7)..21

Tais reformas eram realizadas com o objetivo de ressaltar ainda mais a tradição romana, visto que os templos eram restaurados de modo a continuar com todas as características arcaizantes que lhes eram próprias, com os materiais costumeiramente utilizados na tradição arquitetônica itálica e com o mesmo estilo que possuíam antes das restaurações. Zanker (2005, p. 286) assinala que um estilo arcaico era utilizado já desde o século $\mathrm{V}$ a.C. para determinadas funções religiosas e que, durante o governo de Otaviano, estas formas arcaicas, que representavam uma antiga tradição, floresceram e tinham, então, uma "singular irradiação religiosa".

Com relação especificamente à restauração destes templos, o próprio Augusto declarou: "Reformei oitenta e dois templos dos deuses na Vrbs em meu sexto consulado e pela autoridade senatorial, nada negligenciando do que era, então, preciso reformar" (Res Gestae Diui Augusti, XX).

Essas restaurações não faziam parte da ambiciosa transformação de Roma de uma cidade de tijolos para uma cidade de mármore, pois tais restaurações com a permanência da aparência original podem facilmente ser tomadas como demonstrando o sentido de Otávio Augusto de religio (Galinsky, 1998, p. 295), ou seja, manter uma ligação cósmica com as divindades sem alterar os canais pelos quais esta ligação se estabelecia, no caso os templos religiosos.

Além disso, as reformas de tais templos se ligavam a uma mais ampla restauração religiosa e dos ritos tradicionais que Otávio também empreendeu. De

\footnotetext{
${ }^{21}$ Posteriormente, Suetônio em seu tempo também cita este empreendimento de Otaviano, afirmando que este refez velhos templos ornando-os com doações riquíssimas (De Vita Caesarum, Diuus Augustus, XXX).
} 
acordo com John Scheid (2007, p. 177), a restauração empreendida por Augusto foi uma reação contra a negligência dos deveres rituais públicos e dos templos, ocorrida devido às desordens das guerras civis, e estas restaurações eram parte de seus objetivos políticos, visto que "restaurar a Res Publica automaticamente significava restaurar suas instituições religiosas e lugares de culto, especialmente quando eles tinham sido negligenciados ou mesmo esquecidos”. Diane Favro, em alguns trabalhos seus (1992, p. 61; 2007, p. 242), também afirma que antes do governo de Otávio Augusto, templos e outras estruturas públicas sofreram com décadas de negligência.

No que se refere à suposta negligência de manutenção dos templos antes do governo de Otávio Augusto, Mary Beard, John North e Simon Price (1998, p. 122) questionam se isto não seria uma falsa representação, pois, segundo eles, com uma cuidadosa pesquisa através das referências aos projetos de construções religiosas do fim da República, bem como das evidências arqueológicas remanescentes, pode-se "produzir uma imagem bastante clara da fundação regular de novos templos e da contínua manutenção dos antigos ao longo dos últimos anos da República”, o que coloca a teoria da negligência em cheque.

Seja como for, o que nos interessa aqui é sublinhar que, havendo ou não negligência, esta foi a imagem passada por Augusto e seu grupo, de tal forma que a restauração de edifícios públicos foi uma das principais formas de demonstrar o retorno da estabilidade e da prosperidade, e, no que concerne à arquitetura religiosa, demonstrava o comprometimento do Princeps com a busca e a manutenção da pax deorum, através do cumprimento dos deveres que competiam a ele e aos demais cidadãos.

Acreditamos que a restauração religiosa empreendida por Otaviano ao longo de seu governo, e que teve início com as reformas dos templos em 28 a.C., foi utilizada como propaganda pelo Princeps e seu grupo de apoio.

Durante sua ascensão de Otaviano a Augusto, a religião serviu ao jovem ambicioso como uma excelente ferramenta de propaganda, não apenas para fortalecer sua posição em Roma, mas também para declarar sua legitimidade no tempo da guerra civil, especialmente com relação ao grupo de Antônio (Hesse, 2014, p. 88).

Com relação a esta temática, Scheid (2009, p. 122-123) defende que as iniciativas de Otaviano, no que se refere à restauração religiosa, não devem ser 
vistas como propaganda, afirmando que propaganda não era um conceito que se aplicava a Augusto e à Antiguidade. Mas este autor tem uma concepção de propaganda diferenciada da utilizada por nós, pois enquanto para nós a propaganda pode ser definida como "o simples, mas importante, ato de organizar, selecionar e divulgar informações, com o uso de persuasão, de síntese e de imagens que estão na memória dos receptores das mensagens" (Ellul, 1957 apud Gonçalves, 2013, p. 45), para Scheid (2009, p. 122-123) a propaganda está mais relacionada ao engodo e à propagação de informações baseada apenas na intenção de convencer, sem estar necessariamente baseada na verdade, já que, para defender a tese de que propaganda não se aplica a Augusto, ele lança mão da justificativa de que os contemporâneos de Otaviano nunca duvidaram de sua sinceridade e jamais zombaram de sua piedade; para este autor, essas reformas, juntamente com suas outras iniciativas religiosas, como a construção de templos, fizeram o Princeps parecer aos olhos de seus contemporâneos como um homem de piedade exemplar.

Acreditamos que uma coisa não exclui a outra, ou seja, as reformas de Otávio podem ter sido baseadas numa intenção sincera de restaurar os templos e as antigas tradições que estavam em desuso, ao mesmo passo que também foram amplamente propagadas para reforçar uma imagem positiva de Otaviano e de seu governo. Mesmo porque,

$\mathrm{O}$ ato de propagandear, de divulgar uma informação, de fazer uma comunicação, pode conter em si um limite de veracidade, pois trabalha com idealizações e com formação de opiniões, mas esta idealização não pode exceder este limite, pois nenhum governo se mantém muito tempo alicerçado em fatos completamente mentirosos e/ou deformados. É necessário usar de imaginação e criatividade para se transformar a realidade e deixar aparecer somente os fatos positivos a respeito do governante, e ainda usar símbolos para unir a pátria, criar imagens e articular dados para conseguir uma coesão mínima (Gonçalves, 2013, p. 45).

Cremos que foi justamente assim que agiram Otaviano e seu grupo, ao selecionar e manipular informações, histórias, mitos e representações imagéticas na construção de uma memória e de uma imagem positiva de seus feitos, de seu governo e de seu nome; e dentre os meios utilizados por eles, ressaltamos ao longo deste trabalho o papel de destaque da arquitetura para conseguir seus objetivos.

Além das restaurações, não poderíamos deixar de falar aqui sobre outra importante construção que Otávio Augusto empreendeu. Trata-se do templo de 
Apolo, sobre o Palatino, associado ao ano de 36 a.C., ano da vitória sobre Sexto, em Nauloco. Este é o ano em que foi decidida a construção do templo de Apolo Palatino. ${ }^{22}$ Em 28 a.C. o templo foi finalmente consagrado.

Este templo é de suma importância para a compreensão deste contexto, pois demonstra claramente alguns aspectos presentes no modo de governar de Augusto, que adota este deus de modo a associar-se a algumas das características que lhe eram próprias, tais como a moral e a disciplina. Segundo Galinsky (1998, p. 213-215), a colina do Palatino era a mais venerável colina de Roma, pois nela se encontrava a gruta Lupercal, onde a lendária loba havia amamentado Rômulo e Remo, e no topo da colina estava a cabana de Rômulo, que foi preservada e renovada através da história de Roma. Além disso, nesta colina se encontravam um templo dedicado à deusa Vitória e um altar dedicado à Vitória Virgo. Com a construção do templo de Apolo, no Palatino, "Otaviano associou-se tanto com Vitória - um tema geral que ele perseguiu na época - quanto com algumas das mais sagradas tradições da fundação de Roma” (Galinsky, 1998, p. 215).

Deste modo, após adquirir, com recursos próprios, um espaço para a construção de sua casa no Palatino, um raio atingiu o lugar, o que foi tomado como um prodigium e interpretado pelos arúspices como um desejo de Apolo por aquela área. Deste modo, Otávio Augusto fez de toda aquela área um lugar público, dedicando-o a Apolo, mas o povo resolveu que a casa deveria ser oferecida a Otávio Augusto às expensas públicas (Dion Cássio História Romana, XLIX, 15).

Assim, o templo foi construído lá, e ele estava ligado à sua casa. Após a vitória em Ácio, Apolo, cuja proteção a Otávio Augusto tinha sido sugerida pelo prodigium de 36 a.C. e suas consequências, assumiu a papel de um poderoso protetor e deus da guerra. [...] Com o seu esplendor, seus pórticos e bibliotecas, o templo de Apolo era um símbolo do novo regime imperial (Scheid, 2007, p. 179).

Este templo possuía uma colunata coríntia e foi construído com um branco mármore de Luna sobre um alto pódio. O alto do templo estava coroado

\footnotetext{
${ }^{22}$ Apesar desta associação com a batalha de Nauloco, concordamos com autores como Carsten $\mathrm{H}$. Lange (2009, p. 167) e Olivier Hekster e John Rich (2006, p. 149-150), que, em seus respectivos trabalhos, esclarecem que a construção do Templo de Apolo Palatino não se deu devido a uma oferta feita como um ato de ação de graças pela vitória na Sicília, mas sim após o local ter sido atingido por um raio, visto, assim, como um prodigium, que devia ser expiado com a construção de um templo.
} 
pela quadriga do deus Sol, que se identificava com Apolo desde os tempos helenísticos. As portas do templo eram feitas de marfim, sobre as quais foram esculpidas cenas mitológicas, tais como a que alude à punição que Apolo confere a Níobe por esta ter ridicularizado Latona, mãe de Apolo, pelo fato de ter tido menos filhos que ela própria. "Apolo assim aparece como salvador e vingador, duas características que ressoaram no contexto augustano muito além de uma mera referência à batalha de Ácio" (Galinsky, 1998, p. 218-219).

O templo de Apolo, assim, possuía estreita ligação com Otávio Augusto e sua casa, constituindo um verdadeiro complexo arquitetônico, no qual o templo estaria ligado à casa de Augusto, e tinha ligado a ele uma biblioteca onde se encontravam textos de escritores gregos e latinos. Além disso, como ressalta Haselberger (2007, p. 90), a inauguração do templo de Apolo, no Palatino, sublinhava uma importante inovação, pois já existia em Roma um templo dedicado ao deus Apolo23, no entanto este se encontrava localizado fora do pomerium, 24 "agora 0 deus mudou-se até uma esplêndida casa nova sobre a colina Palatina, 'dentro' da casa do governante, que vivia junto com ele; Apolo definitivamente se tornou a 'divindade principal' da nova era” (Haselberger, 2007, p. 90).

A consagração do Templo de Apolo, em certa medida, foi a culminância da política adotada por Otávio Augusto desde os tempos do triunvirato, quando buscava denegrir a imagem de Antônio e sua excessiva proximidade com Cleópatra e o estilo de vida luxuoso e extravagante do Oriente.

Antônio era visto como favorecendo divindades orientais e apreciando uma vida de luxo e decadência. A decisiva batalha de Ácio era retratada como o conflito final entre as refinadas e civilizadas qualidades romanas e as bárbaras tradições do Egito e do Oriente. A batalha não foi entre dois romanos, mas entre Roma e Augusto de um lado e Egito e Cleópatra do outro (Hope, 2005, p. 73).

23 O templo de Apolo in circo, construído no Campo de Marte próximo ao Circo Flamínio, ou Apolo Medicus foi prometido em 433-432 a.C. em consequência de uma praga e foi dedicado em 431 pelo cônsul C. Iulius. O templo também é conhecido como Templo de Apolo Sosiano, pois foi reconstruído em 32 a.C. pelo consul C. Sosius.

$24 \mathrm{O}$ pomerium delimitava as fronteiras religiosas e jurídicas da cidade; fronteiras religiosas no que diz respeito à delimitação do templum, o espaço ritualmente inaugurado; e fronteiras jurídicas no que diz respeito à separação do domínio dos magistrados com Imperium, poder de comando militar que não poderia ser usado dentro do pomerium. 
De acordo com Richard Beacham (2007, p. 158), em contraste com a sensual autoindulgência e o licencioso dionisismo completamente incorporado pelas excentricidades de Antônio, se erguia Apolo pela disciplina, moralidade e moderação. "Estas tradicionais virtudes romanas agora eram exigidas urgentemente para a missão vital de criar uma nova ordem, digna do passado de Roma" (Beacham, 2007, p. 158). Com Apolo, Otávio Augusto firmava de modo claro seu comprometimento com as tradições ancestrais, sejam elas romanas ou gregas. A meta dele "consistia não só em imitar o melhor dos gregos, mas em criar algo que fosse equivalente a sua cultura clássica” (Zanker, 2005, p. 114). Com isso, Galinsky chega a afirmar que:

Os novos templos eram uma manifestação visual esplêndida de sua auctoritas. A descoberta das jazidas de mármores de Luna (Carrara) em meados do primeiro século a.C. permitiu aos construtores de Otávio Augusto rivalizar os templos gregos em magnificência, gasto e riqueza de detalhes. O resultado foi a usual síntese: a herança itálica do pódio foi mantida e combinada com a mais elaborada das ordens arquiteturais gregas, o estilo coríntio (Galinsky, 1998, p. 295).

Além disso, os templos possuíam um importante papel relacionado à memória e à história, servindo em muitos casos como verdadeiro monumento histórico, como lugar de memória, mantendo viva a memória relacionada à pessoa que o edificou ou ao contexto por trás de tal construção. Como afirma Eric Orlin:

Os templos romanos [...] serviam não apenas como loci para a atividade ritual ao fornecer lugares para a religião romana, mas também como monumentos nos quais as memórias romanas e a história romana residiam. [...] À medida que os espectadores encontram um templo, sua atenção é atraída para a pessoa específica que o construiu e o evento específico que ele comemora, e são lembrados, assim, das realizações de seus antepassados e do que significa ser romano (Orlin, 2007, p. 83).

Deste modo, Otávio Augusto se utilizou da arquitetura religiosa como forma de propagar uma imagem positiva de si e de suas vitórias, pois, após regressar a Roma no ano de 29 a.C., ele inaugurou o templo do Divino Júlio César, no Fórum Romano, ricamente decorado com os rostra dos navios derrotados na batalha de Ácio. No ano seguinte, ele restaurou 82 templos, além de consagrar o esplêndido templo de Apolo, no Palatino, intimamente relacionado com a sua casa. 
Apesar de nos concentrarmos aqui nos anos posteriores à sua vitória sobre Marco Antônio e Cleópatra, devemos lembrar que a importância conferida por Augusto à arquitetura, de modo geral e à arquitetura religiosa, de modo específico, perpassou todo seu governo. De forma que nas Res Gestae (XIX e XXI), Augusto fez questão de afirmar que construiu (feci) os templos de Apolo no Palatino, do Diuus Iulius, de Júpiter Ferétrio, de Júpiter Tonante no Capitólio, de Quirino, de Minerva, da Rainha Juno, de Júpiter da Liberdade no Aventino, dos Lares no topo da Via Sacra, dos deuses Penates em Vélia, da Juventude e o de Magna Mater no Palatino, além do Templo de Marte Vingador. No entanto, não temos muitas informações sobre todos estes templos, de modo que não se sabe a data de consagração ou o local de muitos deles. Além disso, como esclarece Haselberger (2007, p. 218), alguns destes templos foram na verdade restaurados pelo Imperador e não construídos. Deste modo, foi "um total de três templos que Augusto erigiu ex novo, completamente por sua própria iniciativa e inteiramente com seus próprios fundos” (Haselberger, 2007, p. 88), que são o templo de Apolo, no Palatino, o templo de Júpiter Tonante, no Capitólio e o templo de Marte Vingador em seu novo Fórum. Na opinião de Suetônio (De Vita Caesarum, Diuus Augustus. XXIX), estes três templos foram as principais obras públicas realizadas por Augusto.

\section{Considerações finais}

Em seu governo, Otávio Augusto empreendeu não só a construção do Império no que tange à arquitetura, mas também a construção de todo um imaginário imperial, a partir da arquitetura e do repertório imagético representado nela, fazendo assim o uso e manipulação das representações advindas de uma memória coletiva que tinha, na arquitetura, um lugar de destaque.

Em 27 a.C., Otávio Augusto mudou de postura, pondo fim, assim, ao que Walter Eder (2007, p. 23) chama de "Período Otaviânico". No período tratado neste trabalho, segundo Eder, Otávio Augusto teria gasto aproximadamente 1 bilhão de sestércios de modo a provar seu cuidado e interesse com o povo de Roma, bem como seu respeito pelos antigos deuses de Roma ou, "sob um ponto de vista diferente, ele tentou comprar seu reconhecimento como Primeiro Cidadão e o maior benfeitor". 
Podemos considerar este período posterior à vitória em Ácio como um período de grande importância no governo de Otávio Augusto, quando ele demonstrou ainda mais a importância da arquitetura para o engrandecimento de Roma, como sede de um vasto Império territorial e capital do mundo conhecido, demonstrando também sua atenção e respeito à religião e aos costumes ancestrais.

Nos anos de 29 e 28 a.C., Otaviano se utilizou de uma estratégia que já havia iniciado no período do Triunvirato e de que se utilizaria durante todo o seu governo, qual seja, a estratégia de usar da arquitetura não apenas para o engrandecimento e monumentalidade de Roma, como também de propaganda de uma imagem positiva de si e de seus feitos. Portanto, o Princeps soube lançar mão da arquitetura para demonstrar seu poder, adquirido após a vitória nas importantes batalhas de Ácio e Alexandria, bem como para demonstrar seu prestígio, seu respeito à religião e às tradições ancestrais. Ao usar a arquitetura para perpetuar uma imagem boa de si e de seus feitos, inserindo seu nome na memória dos vindouros, ele a instrumentalizou como ferramenta para auxiliá-lo na construção e manutenção do Principado que se iniciava com ele, se tornando um exemplo a ser seguindo pelos futuros imperadores.

Artigo recebido em 04.06.2017, aprovado em 18.12.2017. 


\section{REFERÊNCIAS BIBLIOGRÁFICAS}

\section{Fontes Primárias}

Grumel, Venance. Le patriarcat byzantine. Série I, les regestes des actes du patriarcat de Constantinople. V. 1, Les actes patriarches, fasc. II et III. Les regestes de 715 à 1206. Paris: Institut Français d'Études Byzantines, 1989. Deuxiême edition revue et corrigée par Jean Darrouzès, 1989.

Mango, Cyril. The Art of the Byzantine Empire, 312-1453: Sources and Documents. Toronto: University of Toronto Press, 1993.

\section{Bibliografia Crítica}

Abulafia, David. O grande mar: uma história humana do Mediterrâneo. Tradução: Cássio de Arantes Leite. $1^{\mathrm{a}}$ Edição. Rio de Janeiro: Objetiva, 2014. p. 237280 .

Auzépy, Marie-France. State of emergency (700-850). In: SHEPARD, Jonathan. The Cambridge History of the Byzantine Empire. Cambridge: Cambridge University Press, 2008, p. 251-291.

Bajjani, Lucy Cavallini. Estudo dos 'Libri Carolini': uma contribuição para o estatuto da imagem na Idade Média. Dissertação de Mestrado. São Paulo: FFLCH/ USP, 2009.

Barros, José D’Assunção. Império e papado na Idade Média: reflexões historiográficas sobre duas realidades em conflito. Revista Textura: Canoas, n. 14, 2006, p. 47-57.

Bayly, C.A.; Beckert, Sven; Connely, Matthew; Hofmeyr, Isabel; Kozol, Wendy; Seed, Patricia. AHR Conversation: On Transnational History. American Historical Review 111, no. 5, December 2006, p. 1440-1464.

Besançon, Alain. A imagem proibida. Uma história intelectual da Iconoclastia. Rio de Janeiro: Bertrand Brasil, 1997.

Bibiane, Daniela; Tôrres, Moisés Romanazzi. A evolução política da Alta Idade Média na Europa Ocidental: da pluralidade dos Reinos Romano-Germânicos à Unidade Carolíngia. Revista Brathair, 2 (1), 2002, p. 03-13.

Bíblia, Português. A Bíblia Sagrada. Edição Pastoral. [Tradução de Ivo Storniolo e Euclides Martins Balancin]. São Paulo: Sociedade Bíblica Católica Internacional e Paulus, 1990.

Boy, Renato Viana. Bizâncio, o Oriente semita e a querela das imagens. Séculos VIII e IX. Monografia de bacharelado. UFOP. DEHIS, 2004.

A Querela Iconoclasta: uma disputa em torno dos ícones no Império Bizantino- 726-843. Dissertação de Mestrado. Rio de Janeiro: UFRJ/IFCS, 2007.

Cormack, Robin; Haldon, John; Jeffreys, Elizabeth (Eds.). The Oxford Handbook of Byzantine Studies. Oxford: Oxford University Press, 2008.

Ficker, Sandra Kuntz. Mundial, trasnacional, global: Un ejercicio de clarificación conceptual de los estudios globales. IN: Nuevo Mundo Mundos Nuevos, Débats, mis en ligne le 27 mars 2014. 
Gregory, Timothy E. A History of Byzantium. Oxford: Blackwell Publishing, 2005.

Guarinello, Norberto Luiz. Ordem, Integração e fronteiras no Império Romano: um ensaio. Mare Nostrum, ano 2010, vol. 1, p. 113-127.

Haldon, John. Iconoclasia en Bizancio: mitos y realidades. Anales de Historia Antigua, Medieval y Moderna, Buenos Aires, v. 42, 2010.

. Political-Historical survey 518-8oo. Cormack, Robin; Haldon, John; Jeffreys, Elizabeth (Edited by). The Oxford Handbook of Bizantine Studies. Oxford: Oxford University Press, 2008. p. 249-263.

Hartog, François. Experiência do tempo: da história universal à história global?. IN: história, histórias. Brasília, vol. 1, n. 1, 2013. p. 164-179.

Kazhdan, Alexander P. The Oxford Dictionary of Byzantium. 3 vols. New York Oxford: Oxford University Press, 1991.

Kirk, George E. História do Oriente Médio. [Tradução: Álvaro Cabral]. Rio de Janeiro: Zahar Editores, 1967, p. 25-79.

Le Goff, Jacques; Schmitt, Jean-Claude (Coord.). Dicionário Temático do Ocidente Medieval. [Coordenação da Tradução: Hilário Franco Júnior]. Bauru: EDUSC; São Paulo: Imprensa Oficial do Estado, 2002, 2 v.

Lemerle, Paul. História de Bizâncio. [Tradução: Marilene Pinto Michael]. São Paulo: Martins Fontes, 1991.

Maier, Franz Georg. Historia Universal Siglo XXI, Bizâncio. México: Siglo XXI de Espana Editores, 1986.

. Las transformaciones del mundo mediterráneo. Siglos III-VIII. 13 edición. México: Siglo Veinteuno editores, 1989.

Morris, Ian. Mediterraneanization. Mediterranean Historical Review, Vol.18, No.2, December 2003, p.30-55.

Negrau, Elisabeta. The ruler's portrait in Byzantine art: a few observations regarding its functions. European Journal of Science and Theology, Vol.7, $\mathrm{N}^{\circ} .2$, 2011. p. 63-75.

Nicholas, Purcell; Peregrine, Horden. The corrupting sea: a study of Mediterranean. Oxford: Blackwell Publishers, 2000. p. 123-172.

Ostrogorsky, Georg. Historia del Estado Bizantino. [Tradução de Javier Facci]. Madri: Akal, 1984. p. 157-216.

Pacheco, Perla. Hacia una nueva historia global no eurocéntrica: un balance crítico. TRASHUMANTE Revista Americana de Historia Social. Mexico, v. 9, 2017. p. 144-165. 